\title{
Does the Resistance to Glyphosate Herbicide Affect the Competitive AbILITY OF RYegrass With SOYBEAN? ${ }^{1}$
}

\author{
A Resistência ao Herbicida Glyphosate Altera a Habilidade Competitiva de Azevém com Soja?
}

OLIVEIRA, C. ${ }^{2}$, AGOSTINETTO, D. ${ }^{2}$, VARGAS, L. ${ }^{2}$, ÁVILA, L.A. ${ }^{2}$, and TAROUCO, C.P. ${ }^{2}$

\begin{abstract}
The objective this work was to investigate the competitive ability between resistant and susceptible ryegrass biotypes and of these with soybean crop. Four experiments were carried under greenhouse, in a completely randomized design with four replications, in 2011 and 2012. Treatments were arranged in additive series and replacement series assay. In each series, the proportions among ryegrass resistant and susceptible plants related to soybean were: 100:0, 75:25, 50:50, 25:75 e 0:100. Leaf area and shoot dry mass were evaluated. Competitiveness statistical analysis consisted in applying diagrams to the replacement series and alternative interpretations of the competitiveness indexes. The soybean crop had equivalent competitiveness to the susceptible ryegrass biotype and inferior to the resistant biotype, while the biotypes, both susceptible and resistant to glyphosate, present equivalent competitive ability. In general, the intraspecific competition is more harmful to ryegrass when in competition with soybean, while interspecific competition is predominant for culture.
\end{abstract}

Keywords: Lolium multiflorum, Glycine max, competition.

\begin{abstract}
RESUMO - O objetivo deste trabalho foi investigar a habilidade competitiva relativa entre biótipos resistentes e suscetiveis de azevém e desses com a cultura da soja. Foram realizados quatro experimentos em casa de vegetação, nos anos de 2011 e 2012. O delineamento utilizado foi o completamente casualizado com quatro repetições, sendo os tratamentos do primeiro experimento arranjados em série aditiva e os dos demais, em série de substituição. Em cada experimento, as proporções entre plantas de soja e azevém suscetivel ou resistente, bem como entre azevém suscetivel e resistente, foram de 100:0, 75:25, 50:50, 25:75 e 0:100. As variáveis avaliadas foram área foliare matéria seca da parte aérea. A análise da competitividade foi feita por aplicação de diagrama e interpretações dos indices de competitividade. A cultura da soja possui competitividade equivalente à do biótipo de azevém suscetivel ao herbicida glyphosate, porém inferior à do biótipo resistente, enquanto esses apresentam habilidade competitiva equivalente. Em geral, a competição intraespecífica é mais prejudicial aos biótipos de azevém quando em competição com a soja, enquanto a competição interespecífica é preponderante para a cultura.
\end{abstract}

Palavras-chave: Lolium multiflorum, Glycine max, competição.

\section{INTRODUCTION}

The soybean (Glycine max) is one of the main oilseeds produced worldwide. The soybean crop area in Brazil, in the harvest of $2011 / 2012$, was approximately 25 million hectares, with a production of about 66 million tons of grain (Conab, 2012). The soybean crop in the country depends mainly on the use of herbicides for the control of weed plants that infest the culture and, as a response to this application, have been a selection of resistant weed plant populations (Heap, 2012).

For some years, the producers have been experiencing difficulties to control the

Recebido para publicação em 15.9.2013 e aprovado em 23.1.2014.

2 Universidade Federal de Pelotas, Pelotas-RS, Brasil, <oliveirac.agro@gmail.com>; ${ }^{3}$ Embrapa Trigo, Passo Fundo RS, Brasil. 
ryegrass (Lolium multiflorum) with glyphosate - commonly used technique. These control faults interfere in the desiccation of the culture areas, thus, even though the ryegrass is a winter species, the establishment of soybean becomes a problem in the initial phases.

Despite being apparently similar physiologically, susceptible and resistant biotypes of ryegrass may present different characteristics regarding the ability to compete with other cultures. The more adapted biotypes are usually more competitive and, therefore, capable of increasing the relative proportion with time and eliminating the ones that are less apt to occupy a certain ecological niche (Christoffoleti et al., 1997).

The competition among plants occurs at least for one of the development and growth resources that is limited to supply the needs of all the individuals in the environment. Can be competition intraspecific and/or interspecific in the environment; depending on the ecological niche, the interspecific competition maybe it's more relevant (Rigoli et al., 2008).

Several methods are being developed to define the competition interactions between weed and cultures. These methods take into consideration the plant population, species proportion and spatial arrangement (Radosevich, 1987). Among the experimental methods, the replacement series method stands out, for it enables the study of inter and intraspecific competition. This type of experiment says the association productivities may be defined in comparison with the monoculture associations, and the total plant population is maintained constant. These experiments aim at identifying the most competitive genotypes or species (Cousens, 1991).

The hypothesis of this research was that the ryegrass biotype that is resistant to glyphosate presents lower competitive ability when compared with the susceptible biotype and that both present lower competitiveness when compared with the soybean crop. Thus, this study aimed at investigating the relative competitive ability between resistant and susceptible ryegrass biotypes and of these with soybean crop.

\section{MATERIAL AND METHODS}

In order to establish the competitive ability between the ryegrass biotypes that are susceptible and resistant to glyphosate, intercropped, and these biotypes with the soybean crop, four experiments were carried out under greenhouse, in a completely randomized design with four replications. The species were sowed in 8 liter pots with $23 \mathrm{~cm}$ of diameter, filled with soil. Seeds from the soybean cultivar CD226RR were used in all experiments. The susceptible ryegrass seeds came from plants that were cultivated in an area where glyphosate was never used (30582'543" south and 54402'393” west), and seeds from the ryegrass biotype that is resistant to glyphosate came from the municipality of Tuparendi-RS $\left(27^{\circ} 45^{\prime} 26^{\prime \prime}\right.$ south and $54^{\circ} 34^{\prime} 27^{\prime \prime}$ west) (Fraga, 2012).

The first experiment, with soybean and ryegrass monocultures, aimed at defining the plant population $\mathrm{m}^{-2}$ where the shoot dry weight (SDW) by area unit $\left(\mathrm{g} \mathrm{m}^{-2}\right)$ becomes independent from the population, in accordance with the "law of constant final yield" (Radosevich et al., 1987). The populations tested were of $1,2,4,8,16,32,64$ and 128 plants per pot (equivalent to 24, 48, 96, 192, 385, 770, 1.540 and 3.080 plants $\mathrm{m}^{2}$ ).

The shoot dry weight (SDW) variable was calculated 40 and 60 days after the emergence (DAE); the plants were weighted after being dried in an oven with forced air circulation at $60{ }^{\circ} \mathrm{C}$ for 72 hours. For the data analysis, the mutual production was used to establish the plant population in which the shoot dry weight was constant. The weight was obtained in a population of 24 plants per pot ( 578 plants $\mathrm{m}^{-2}$ ) for the experiments involving soybean and ryegrass and 36 plants per pot (866 plants $\mathrm{m}^{-2}$ ) for the experiment involving the ryegrass biotypes that are susceptible and resistant to glyphosate. The values were calculated after 40 days for the soybean and after 60 days for the ryegrass (data not presented).

The second and third experiments were carried out in replacement series, associating soybean with the susceptible or resistant ryegrass biotypes, from October to December 2011 , being installed with a population of 24 plants per pot (578 plants $\left.\mathrm{m}^{-2}\right)$. In 
experiments 2 and 3 the soybean sowing was conducted 20 DAE of the ryegrass plants, in order to simulate the plant escape or regrowth that occur after the pre-sowing desiccation of the culture.

The fourth experiment was carried out in replacement series, between the ryegrass biotypes, from May to July 2012, with a population of 36 plants per pot (866 plants $\mathrm{m}^{-2}$ ). The proportions between susceptible (experiment 2) or resistant (experiment 3) soybean and ryegrass plants, as well as the susceptible and resistant ryegrass (experiment 4), were 100:0, 75:25, 50:50, 25:75 and $0: 100$, respectively. The variables evaluated were leaf area (LA) $\left(\mathrm{cm}^{2}\right.$ per plant) and shoot dry weight (SDW) (g per plant) at $40 \mathrm{DAE}$ of the soybean crop and $60 \mathrm{DAE}$ of the ryegrass plants. The leaf area was established with the aid of a leaf area meter (model LI 3100C), shoot dry weight was calculated as described previously.

Regarding the variable analysis of LA and SDW of the cultures and competitors, the relative productivity graphic analysis method was used (Radosevich, 1987; Roush et al., 1989; Cousens, 1991). Such procedure, known as replacement experiments conventional method, consists of the drawing of a diagram based on the relative (RP) and total (TRP) productivities or variations. When results in a straight line, it means the abilities of the species are equivalent. In case the RP results in a concave line, there is growth loss for one or both species. On the contrary, in the RP results in a convex line, there is growth benefit for one or both species. Whenever the TRP is equal to the unit (1) (straight line), there is competition for the same resources, and if it is above 1 (convex line), the competition is avoided. In case the TPR is under 1 (concave line), there is mutual growth loss (Cousens, 1991; Radosevich et al., 2007).

Besides the RP and TRP, the results obtained for leaf area and shoot dry weight of the susceptible and/or resistant soybean and ryegrass plants, expressed in median values by plant, were submitted to variance analysis. When the test $F$ indicated relevance $(p<0,05)$, the treatment medians were compared by Dunnett's test $(p<0,05)$, considering the respective monocultures as witnesses.
The relative competitiveness (RC) indexes and the relative grouping $(\mathrm{K})$ and competitiveness (C) coefficients were calculated. The $\mathrm{RC}$ represents the comparative growth of species $\mathrm{X}$ in relation with species $\mathrm{Y}$; $\mathrm{K}$ indicates the dominance of one species over the other; and $\mathrm{C}$ points which species is more competitive. Thus, indexer $\mathrm{RC}, \mathrm{K}$ and $\mathrm{C}$ indicates the most competitive species and their interpretation as a group shows, with reliability, the competitiveness of the species (Cousens, 1991). Species $X$ is more competitive than $\mathrm{Y}$ when $\mathrm{RC}>1, \mathrm{~K}_{\mathrm{x}}>\mathrm{K}_{\mathrm{y}}$ and $\mathrm{C}>0$; on the other hand, species $\mathrm{Y}$ is more competitive than $\mathrm{X}$ when $\mathrm{RC}<1, \mathrm{~K}_{\mathrm{x}}<\mathrm{K}_{\mathrm{y}}$ and $\mathrm{C}<0$ (Hoffman \& Buhler, 2002). For the calculation of these indexes, the species proportions used were 50:50.

The procedure for the relative productivity or variation statistical analysis included the calculation of the differences for the RP (DRP) values, obtained in proportions of 25,50 and $75 \%$, regarding the hypothetical line values in the respective proportions (Bianchi et al., 2006). The test $t$ was used to evaluate the differences related to the DPR, PRT, RC, K and C indexes (Roush et al., 1989; Hoffman \& Buhler, 2002). The criteria used in order to consider the RP and TRP curves that were different from the hypothetical, or the existence of differences in competitiveness (RC, $\mathrm{K} \mathrm{e} \mathrm{C),} \mathrm{was} \mathrm{that} \mathrm{there} \mathrm{should} \mathrm{be}$ differences by the test $t$ in at least two proportions (Bianchi et al., 2006).

\section{RESULTS AND DISCUSSION}

With a graphical analysis of the combinations of plants of the soybean cultivar CD226RR and the resistant or susceptible ryegrass biotypes, for leaf area and shoot dry weight, it was possible to note that the difference between the obtained and expected RP lines is represented by concave lines, either for the crop or for the competitors (Figures 1 and 2). That shows the competition is unfavorable for both species. Such result confirms the observation made in the competition between soybean and alexandergrass (Agostinetto et al., 2009).

Considering that at least two proportions must be different in order to be relevant, there 

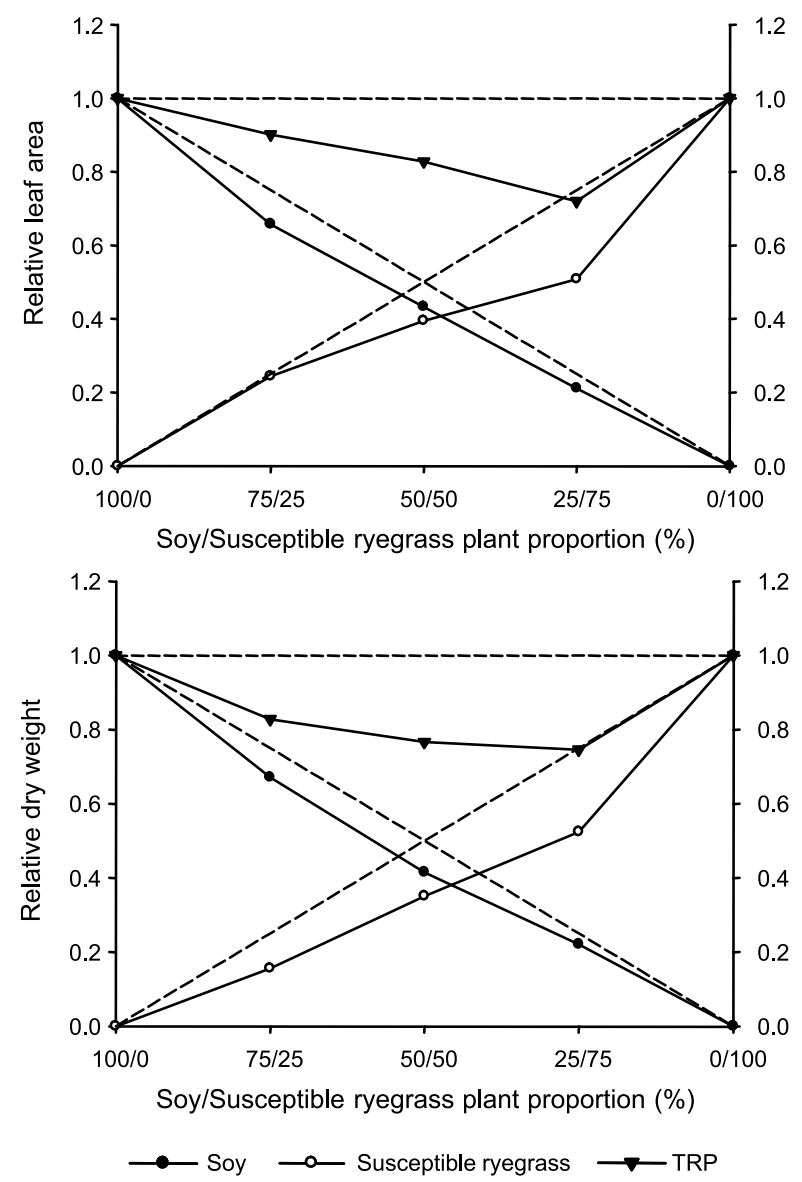

Circles (o) represent the relative productivity of the susceptible ryegrass biotype; dots $(\bullet)$, the relative productivity of the soybean; and triangles $(\boldsymbol{\nabla})$, the total relative productivity. Dashed lines refer to the hypothetical relative productivities, whenever there is no interference of one species over the other.

Figure 1 - Relative (RP) and total (TRP) productivity for the leaf area and shoot dry weight of soybean and ryegrass (Lolium multiflorum) plants, which are susceptible to glyphosate.

are differences for the susceptible ryegrass in both variables (Figure 1; Table 1). The combination of the soybean cultivar with the resistant ryegrass biotype did not show any differences for the RP of the weed plant, in both variables (Figure 2; Table 1). The susceptible biotype result was similar to the one found for the competition between wheat and ryegrass, in which the weed plant presented a leaf area and shoot dry weight reduction (Rigoli et al., 2008; Fraga, 2012).

For the soybean, the RP values were below the expected. The differences for the leaf area
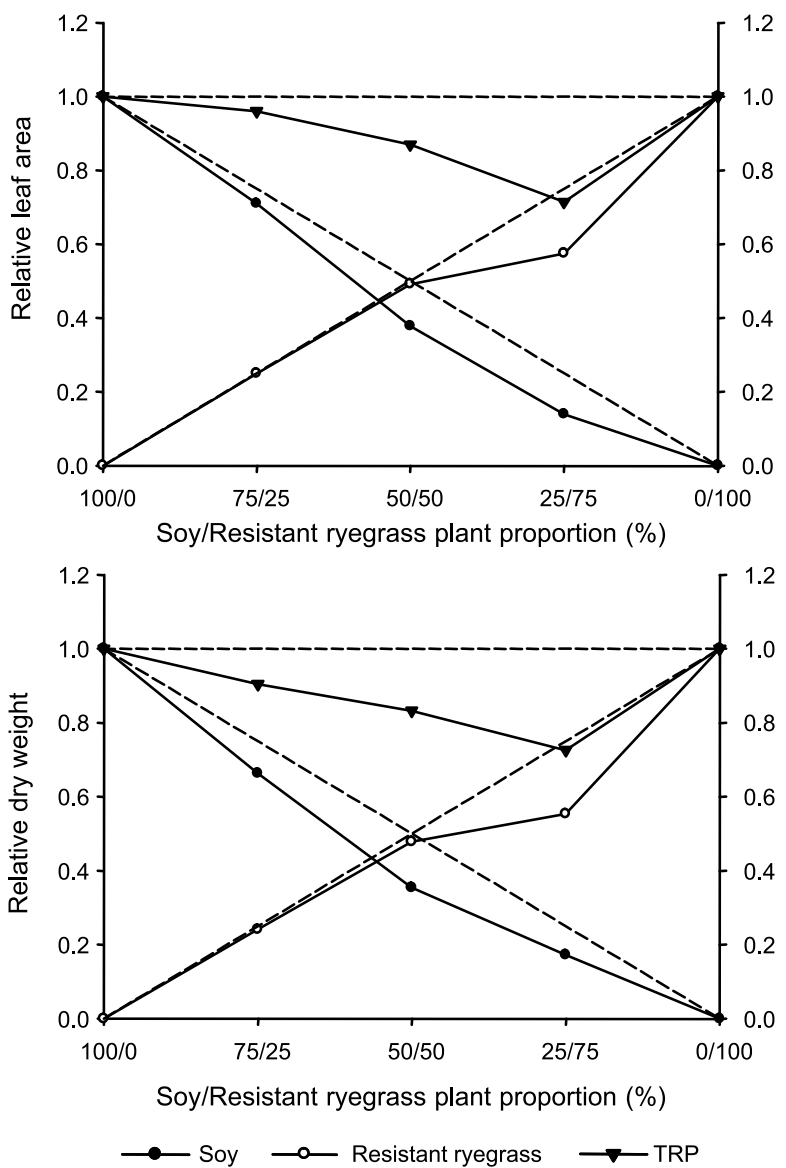

Circles (o) represent the relative productivity of the susceptible ryegrass biotype; dots $(\bullet)$, the relative productivity of the soybean; and triangles $(\boldsymbol{\nabla})$, the total relative productivity. Dashed lines refer to the hypothetical relative productivities, whenever there is no interference of one species over the other.

Figure 2 - Relative (RP) and total (TRP) productivity for the leaf area and shoot dry weight of soybean and ryegrass (Lolium multiflorum) plants, which are resistant to glyphosate.

and shoot dry weight variables were relevant when the soybean was in competition with the resistant biotype (Table 1). Similar results were registered in the competition between soybean and turnip (Bianchi et al., 2006; Silva, 2012). Now, the competition with the red rice crop caused an increase in the shoot dry weight of the soybean plants (Moraes et al., 2009).

Regarding the competition between ryegrass biotypes, the RP results for the leaf area and shoot dry weight showed equivalence, for the estimated lines were similar to the hypothetical ones (Figure 3); thus, the plants 

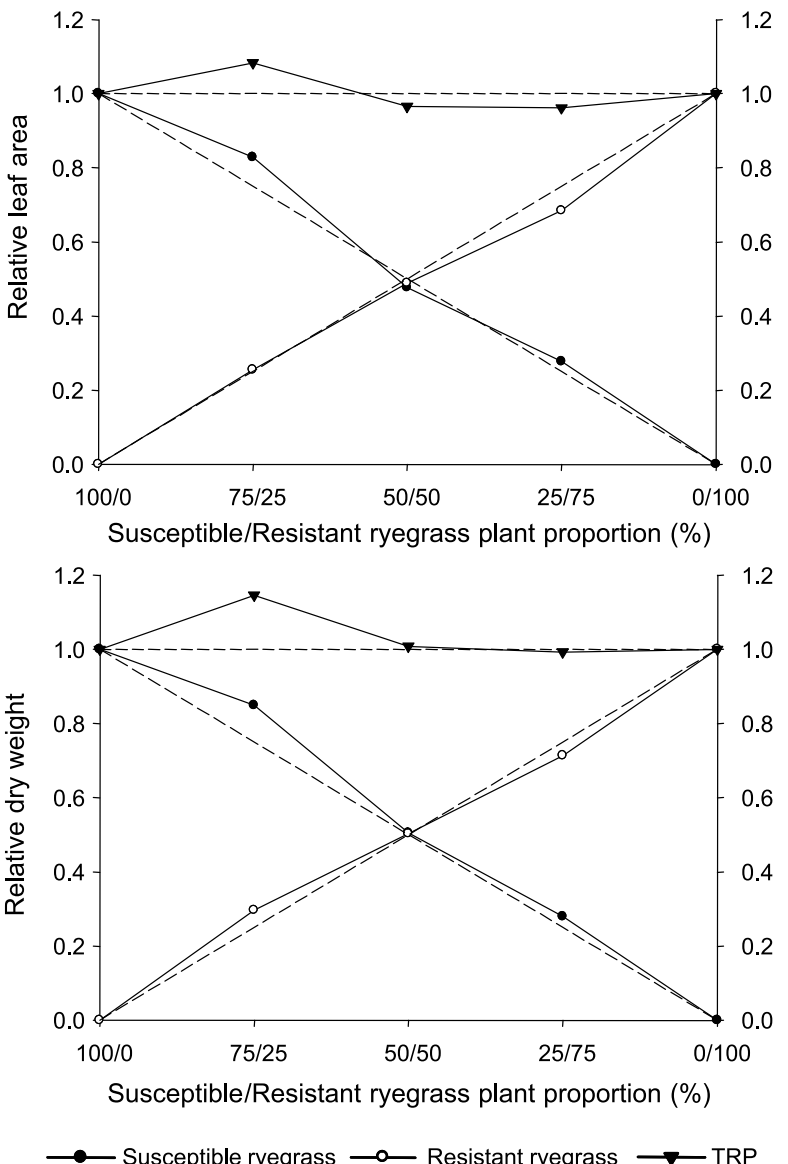

Circles (o) represent the relative productivity of the susceptible ryegrass biotype; dots $(\bullet)$, the relative productivity of the soybean; and triangles $(\boldsymbol{\nabla})$, the total relative productivity. Dashed lines refer to the hypothetical relative productivities, whenever there is no interference of one species over the other.

Figure 3 - Relative (RP) and total (TRP) productivity for the leaf area and shoot dry weight of ryegrass plants, which are susceptible and resistant to glyphosate.

presented equivalent competitive ability, competing for the same resource(s) (Figure 3; Table 1). These results are a consequence of the intrinsic characteristics of the competitors, such as cycle length, shoot dry matter production and height, which may influence their relative growth. Such results confirm the research about competition between ryegrass biotypes that are susceptible and resistant to low levels of herbicides that inhibit the enzyme ACCase (Fraga, 2012).

For the variables studied, the soybean cultivar CD226RR competed with the susceptible ryegrass biotype, there were no differences in the variables regarding the monoculture (Table 2). The leaf area of the susceptible ryegrass reduced when in equal or upper plant proportion (50:50 e 25:75) and the shoot dry weight reduced when in major proportion in the mixture $(25: 75)$. This proves that the intraspecific competition has greater effect for this biotype; this result is similar to the one observed in the competition of ryegrass with wheat (Rigoli et al., 2008).

With the competition of soybean and the resistant ryegrass biotype, it was possible to note a reduction of the morphological variables evaluated for the crop, when in equal or minor plant proportions (50:50 e 25:75) (Table 2). These result showed that the interspecific competition with ryegrass was more harmful for the crop, that means it grows better with its own species. The resistant ryegrass

Table 1 - Relative differences in the productivity for the variables: leaf area and shoot dry weight and total relative productivity, in the plant proportions of biotypes of ryegrass (Lolium multiflorum) that are susceptible and resistant to glyphosate, with soybean, cultivar CD226RR, and between biotypes of ryegrass

\begin{tabular}{|l|c|c|c|}
\hline \multirow{2}{*}{ Biotype } & \multicolumn{3}{|c|}{ Proportion of associated plants $(\%)$} \\
\cline { 2 - 4 } & $75: 25$ & \multicolumn{3}{|c|}{$50: 50$} & $25: 75$ \\
\hline & \multicolumn{3}{|c|}{ Leaf area } \\
\hline Soybean & $-0.09( \pm 0.05)^{\mathrm{ns}}$ & $-0.07( \pm 0.02)^{*}$ & $-0.04( \pm 0.02)^{\mathrm{ns}}$ \\
\hline Susceptible & $-0.01( \pm 0.02)^{\mathrm{ns}}$ & $-0.11( \pm 0.01)^{*}$ & $-0.24( \pm 0.02)^{*}$ \\
\hline Total & $0.90( \pm 0.06)^{\mathrm{ns}}$ & $0.83( \pm 0.02)^{*}$ & $0.72( \pm 0.04)^{*}$ \\
\hline Soybean & $-0.04( \pm 0.01)^{*}$ & $-0.12( \pm 0.01)^{*}$ & $-0.11( \pm 0.02)^{*}$ \\
\hline Resistant & $-0.01( \pm 0.01)^{\mathrm{ns}}$ & $-0.01( \pm 0.02)^{\mathrm{ns}}$ & $-0.11( \pm 0.02)^{*}$ \\
\hline Total & $0.96( \pm 0.01)^{\mathrm{ns}}$ & $0.87( \pm 0.03)^{*}$ & $0.71( \pm 0.02)^{*}$ \\
\hline Susceptible & $0.13( \pm 0.06)^{\mathrm{ns}}$ & $-0.01( \pm 0.03)^{\mathrm{ns}}$ & $0.03( \pm 0.01)^{\mathrm{ns}}$ \\
\hline Resistant & $0.01( \pm 0.02)^{\mathrm{ns}}$ & $-0.01( \pm 0.01)^{\mathrm{ns}}$ & $-0.07( \pm 0.03)^{\mathrm{ns}}$ \\
\hline Total & $1.08( \pm 0.05)^{\mathrm{ns}}$ & $0.96( \pm 0.05)^{\mathrm{ns}}$ & $0.96( \pm 0.02)^{\mathrm{ns}}$ \\
\hline & \multicolumn{3}{|c|}{ Shoot dry weight } \\
\hline Soybean & $-0.09( \pm 0.05)^{\mathrm{ns}}$ & $-0.07( \pm 0.02)^{*}$ & $-0.04( \pm 0.02)^{\mathrm{ns}}$ \\
\hline Susceptible & $-0.01( \pm 0.02)^{\mathrm{ns}}$ & $-0.11( \pm 0.01)^{*}$ & $-0.24( \pm 0.02)^{*}$ \\
\hline Total & $0.90( \pm 0.06)^{\mathrm{ns}}$ & $0.83( \pm 0.02)^{*}$ & $0.72( \pm 0.04)^{*}$ \\
\hline Soybean & $-0.09( \pm 0.04)^{\mathrm{ns}}$ & $-0.15( \pm 0.01)^{*}$ & $-0.08( \pm 0.03)^{*}$ \\
\hline Resistant & $-0.01( \pm 0.04)^{\mathrm{ns}}$ & $-0.02( \pm 0.03)^{\mathrm{ns}}$ & $-0.20( \pm 0.04)^{*}$ \\
\hdashline Total & $0.90( \pm 0.03)^{*}$ & $0.83( \pm 0.03)^{*}$ & $0.73( \pm 0.03)^{*}$ \\
\hline Susceptible & $0.10( \pm 0.03)^{\mathrm{ns}}$ & $0.08( \pm 0.08)^{\mathrm{ns}}$ & $0.08( \pm 0.03)^{\mathrm{ns}}$ \\
\hline Resistant & $0.05( \pm 0.06)^{\mathrm{ns}}$ & $0.01( \pm 0.01)^{\mathrm{ns}}$ & $-0.04( \pm 0.02)^{\mathrm{ns}}$ \\
\hdashline Total & $1.15( \pm 0.02)^{\mathrm{ns}}$ & $1.08( \pm 0.08)^{\mathrm{ns}}$ & $0.99( \pm 0.04)^{\mathrm{ns}}$ \\
\hline
\end{tabular}

${ }^{\mathrm{ns}}$ not relevant and $*$ relevant by the test $\mathrm{t}(\mathrm{p} \leq 0,05)$. Values between brackets represent the standard estimate error. 
Table 2 - Responses for the leaf area and shoot dry weight of biotypes of ryegrass (Lolium multiflorum) that are susceptible and resistant to glyphosate, competing with soybean, cultivar CD226RR, under several plant proportions

\begin{tabular}{|c|c|c|c|c|c|c|}
\hline \multirow{2}{*}{ Biotype } & \multicolumn{6}{|c|}{ Plant Proportion } \\
\hline & $100: 0$ & $75: 25$ & $50: 50$ & $25: 75$ & $0: 100$ & $\mathrm{VC}(\%)$ \\
\hline & \multicolumn{6}{|c|}{ Leaf area $\left(\mathrm{cm}^{2}\right.$ per plant $)$} \\
\hline Soybean & 215.0 & $205.9^{\mathrm{ns}}$ & $186.2^{\mathrm{ns}}$ & $181.5^{\text {ns }}$ & - & 11.19 \\
\hline Susceptible & - & $147.3^{\mathrm{ns}}$ & $119.2 *$ & $102.3 *$ & 150.9 & 10.27 \\
\hline Soybean & 215.0 & $203.6^{\mathrm{ns}}$ & $162.6^{*}$ & $119.0 *$ & - & 6.04 \\
\hline Resistant & - & $128.1^{\mathrm{ns}}$ & $126.0^{\mathrm{ns}}$ & $98.3^{*}$ & 128.2 & 7.48 \\
\hline Susceptible & 134.4 & $148.4^{\mathrm{ns}}$ & $128.1^{\mathrm{ns}}$ & $149.1^{\mathrm{ns}}$ & - & 7.43 \\
\hline \multirow[t]{2}{*}{ Resistant } & - & $156.0^{\mathrm{ns}}$ & $150.5^{\mathrm{ns}}$ & $140.5^{\mathrm{ns}}$ & 154.0 & 8.45 \\
\hline & \multicolumn{6}{|c|}{ Shoot dry weight (g per plant) } \\
\hline Soybean & 1.28 & $1.15^{\mathrm{ns}}$ & $1.06^{\mathrm{ns}}$ & $1.13^{\mathrm{ns}}$ & - & 16.60 \\
\hline Susceptible & - & $1.11^{\mathrm{ns}}$ & $1.10^{\mathrm{ns}}$ & $0.85^{*}$ & 1.16 & 10.05 \\
\hline Soybean & 1.28 & $1.13^{\mathrm{ns}}$ & $0.91^{*}$ & $0.88^{*}$ & - & 17.69 \\
\hline Resistant & - & $1.11^{\mathrm{ns}}$ & $1.10^{\mathrm{ns}}$ & $0.85^{\text {ns }}$ & 1.15 & 19.05 \\
\hline Susceptible & 0.95 & $1.08^{\mathrm{ns}}$ & $0.96^{\mathrm{ns}}$ & $1.07^{\mathrm{ns}}$ & - & 9.22 \\
\hline Resistant & - & $1.40^{\mathrm{ns}}$ & $1.18^{\mathrm{ns}}$ & $1.12^{\mathrm{ns}}$ & 1.18 & 7.22 \\
\hline
\end{tabular}

${ }^{\mathrm{ns}}$ not relevant and * relevant regarding the respective witness $(100 \%)$ by Dunnett's test $(\mathrm{p} \leq 0,05)$. VC - variation coefficient.

biotype, in general, was not affected by the competition; there was only a reduction in the ryegrass leaf area variable when in major plant proportion (25:75).

Unlike this study, researches about the competition between soybeans and other grass species, such as red rice and alexandergrass, showed that the intraspecific competition was more harmful to the crop (Agostinetto et al., 2009; Moraes et al., 2009). Possibly, the results were observed during the soybean emergence period in relation with the ryegrass plants. The weed emergence period, in relation with the soybean emergence, intensifies the weight reduction. The weeds emergence four days before the soybean emergence caused a biomass loss of $42,4 \%$, while the simultaneous emergence reduced 22,7\% (Rizzardi et al., 2004).

When the susceptible and resistant ryegrass biotypes are in competition, there was no effect on the leaf area and shoot dry weight variables (Table 2). That shows the biotypes had equivalent competitive ability, as occurred with the Lolium rigidum biotypes that are resistant to glyphosate and did not differ in competitiveness and growth when compared with the susceptible biotype (Pedersen, et al., 2007).
Considering that the soybean crop is more competitive than ryegrass, when $\mathrm{RC}>1$, $\mathrm{Ks}>\mathrm{Ka}$ and $\mathrm{C}>0$ (Hoffman \& Buhler, 2002), and adopting relevant differences in at least two indexes as a criteria to prove the competitive superiority (Bianchi et al., 2006), it was possible to observe that, for leaf area and shoot dry weight, the soybean presents equivalent competitiveness in relation with the susceptible biotype and inferior competitiveness in relation with the resistant biotype (Table 3). These results differ from the ones reported in the competition of ryegrass biotypes with wheat crop, in which the resistant ryegrass biotype was less competitive in the presence of wheat, presenting a lower vegetative growth (Vila-Aiub et al., 2009). Besides that, it presented a small production of seeds and lower competitive ability when compared with the susceptible biotypes (Ferreira et al., 2008).

The relative growth of the intercropped ryegrass biotypes represented by the RC index, was less or equal to 1 for the variables studied, showing that the biotypes are equal regarding their growth (Table 3). The indexes $\mathrm{K}$ and $\mathrm{C}$ did not differ either, proving that the biotypes are equal regarding their competitive ability. A possible reason for the biotypes not to differ in competitiveness is their 
morphophisiological similarities, for they belong to the same species (L. multiflorum); even though they do not have a common origin, they behave similarly and explore the same ecological niche. Similar results were reported for Cyperus difformis biotypes that are resistant and susceptible to ALS inhibitor herbicides (Dal Magro et al., 2011) and Digitaria ciliaris biotypes that are resistant and susceptible to ACCase inhibitor herbicides (López-Ovejero et al., 2007). On the other hand, different results were found for Conyza canadensis, whose glyphosate resistant biotype was more competitive than the susceptible one (Shrestha et a1., 2010), and for Lolium multiflorum, whose glyphosate susceptible biotype presented higher competitive ability than the resistant one, causing greater damage to the wheat crop (Ferreira et al., 2008).

With an integrated graphical analysis interpretation of the variables regarding the morphology and competitiveness indexes, in general, it is possible to note greater competition effects of the resistant ryegrass biotype over the soybean cultivar CD226RR. However, when the susceptible and resistant ryegrass biotypes are intercropped, both show a similar competitive ability.

The strongest competition effects of the resistant biotype over the soybean may result from morphological differences between the susceptible and resistant plant biotypes; yet these differences have not influenced the competitive ability of these intercropped biotypes. Comparisons between plant biotypes that are resistant and susceptible to herbicides indicated a change in the morphological characteristics of the populations, such as leaf shape and angle, leaf hairiness and root growth (Warwick, 1990).

It is important to note that the replacement experiments are said to be inadequate to define the population dynamics of two competing species with time. Thus, it is not possible to foresee if the less competitive species will suffer a population reduction (Cousens, 1991).

In cases where the resistant biotypes are less competitive, crop techniques, such as increase of plant number by area and/or reduction of the space between rows, may be used as an aid to suppress their growth (Vargas $\&$ Silva, 2009). However, the results of the present study showed there are no adaptability differences between the L. multiflorum biotypes that are resistant and susceptible to glyphosate. Thus, even if this herbicide is no longer used in areas with ryegrass resistance problems, the resistant populations would not be reduced. Therefore, the adoption of practices that make use of control methods other than the chemical control, such as the mechanical, to handle the ryegrass resistance in soybean, is more adequate.

Table 3 - Indexes of competitiveness between biotypes of ryegrass (Lolium multiflorum) that are susceptible and resistant to glyphosate, competing with soybean, cultivar CD226RR, expressed by relative competitiveness (RC), relative grouping (K) and competitiveness (C) coefficients

\begin{tabular}{|c|c|c|c|c|}
\hline & $\mathrm{RC}$ & $\mathrm{Ks}^{3 /}$ & Kas & $\mathrm{C}$ \\
\hline \multicolumn{5}{|c|}{ Soybean : Susceptible } \\
\hline $\mathrm{LA}^{\frac{1}{\prime}}$ & $1.10( \pm 0.07)^{\mathrm{ns}}$ & $0.77( \pm 0.06)^{\mathrm{ns}}$ & $0.65( \pm 0.02)$ & $0.04( \pm 0.03)^{\mathrm{ns}}$ \\
\hline \multirow[t]{2}{*}{$\mathrm{SDW}^{2 / 1}$} & $1.20( \pm 0.11)^{\mathrm{ns}}$ & $0.72( \pm 0.03)^{\mathrm{ns}}$ & $0.55( \pm 0.04)$ & $0.06( \pm 0.03)^{\mathrm{ns}}$ \\
\hline & $\mathrm{RC}$ & $\mathrm{Ks}$ & Kar & $\mathrm{C}$ \\
\hline \multicolumn{5}{|c|}{ Soybean : Resistant } \\
\hline $\mathrm{LA}^{\underline{1 /}}$ & $0.77( \pm 0.04)^{*}$ & $0.61( \pm 0.01)^{*}$ & $0.98( \pm 0.09)$ & $-0.11( \pm 0.02)^{*}$ \\
\hline $\mathrm{SDW}^{\underline{2} /}$ & $0.75( \pm 0.06)^{*}$ & $0.55( \pm 0.02)^{*}$ & $0.94( \pm 0.12)$ & $-0.12( \pm 0.04)^{*}$ \\
\hline & $\mathrm{RC}$ & Kas & Kar & $\mathrm{C}$ \\
\hline \multicolumn{5}{|c|}{ Susceptible : Resistant } \\
\hline $\mathrm{LA}^{\underline{1} /}$ & $0.98( \pm 0.11)^{\mathrm{ns}}$ & $0.94( \pm 0.18)^{\mathrm{ns}}$ & $0.96( \pm 0.02)$ & $-0.01( \pm 0.05)^{\mathrm{ns}}$ \\
\hline $\mathrm{SDW}^{2 /}$ & $1.00( \pm 0.08)^{\mathrm{ns}}$ & $1.04( \pm 0.14)^{\mathrm{ns}}$ & $1.01( \pm 0.02)$ & $0.01( \pm 0.04)^{\mathrm{ns}}$ \\
\hline
\end{tabular}

${ }^{1 /}$ Leaf area; ${ }^{2 /}$ shoot dry weight; ${ }^{3 /} \mathrm{Ks}$ - soybean; Kas - susceptible ryegrass; Kar - resistant ryegrass; ns Not relevant and * relevant by the test $\mathrm{t}(\mathrm{p} \leq 0,05)$. Values between brackets represent the standard estimate error. 
The experiment results show that the soybean crop has the same competitiveness ability as the ryegrass biotype that is susceptible to glyphosate, but it is inferior to the resistant biotype, while these biotypes present equivalent competitive ability. Yet, in general, the intraspecific competition is more harmful to the ryegrass biotypes, when in competition with the soybean, whilst the interspecific competition is predominant for the crop.

\section{LITERATURE CITED}

AGOSTINETTO, D. et al. Competitividade relativa da soja em convivência com papuã (Brachiaria plantaginea). Sci. Agr., v. 10, n. 3, p. 185-190, 2009.

BIANCHI, M. A.; FLECK, N. G.; LAMEGO, F. P. Proporção entre plantas de soja e plantas competidoras e as relações de interferência mútua. Ci. Rural, v. 36, n. 5, p. 1380-1387, 2006.

CHRISTOFFOLETI, P. J.; WESTRA, P.; MOORE, F. Growth analysis of sulfonylurea - resistant and susceptible kochia (Kochia scoparia).Weed Sci., v. 45, n. 5, p. 691-695, 1997.

COMPANHIA NACIONAL DE ABASTECIMENTO CONAB. Disponível em: <http://www.conab.gov.br/ OlalaCMS/uploads/arquivos/12_06_12_16_15_32_boletim_ portportu_junho_2012.pdf $>$. Acesso em: 7 out. 2012.

COUSENS, R. Aspects of the design and interpretation of competition (interference) experiments. Weed Technol., v. 5, n. 3, p. 664-673, 1991.

DAL MAGRO, T. et al. Habilidade competitiva entre biótipos de Cyperus difformis L. resistente ou suscetível a herbicidas inibidores de ALS e destes com arroz irrigado. Bragantia, v. 70, n. 2, p. 294-301, 2011.

FERREIRA, E. A. et al. Potencial produtivo de biótipos de ryegrass (Lolium multiflorum). Planta Daninha, v. 26, n. 2, p. 261-269, 2008.

FRAGA, D. S. Resposta de Lolium multiflorum Lam. aos herbicidas inibidores da enzima ACCase. 2012. $77 \mathrm{f}$. Dissertação (Mestrado em Fitossanidade) - Universidade Federal de Pelotas, Pelotas-RS, 2012.

HEAP, I. Internacional survey of herbicide resistant weeds. Disponível em: < www.weedscience.org $>$. Acessos em: 25 nov. 2012; 10 jan. 2013.

HOFFMAN, M. L.; BUHLER, D. D. Utilizing Sorghum as functional model of crop-weed competition. I. Establishing a competitive hierarchy. Weed Sci., v. 50, n. 4, p. 466-472, 2002.

Planta Daninha, Viçosa-MG, v. 32, n. 1, p. 189-196, 2014
LÓPEZ-OVEJERO, F. R. et al. Crescimento e competitividade de biótipos de capim-colchão resistente e suscetível aos herbicidas inibidores da acetil coenzima A carboxilase. Pesq. Agropec. Bras., v. 42, n. 1, p. 1-8, 2007.

MORAES, P. V. D. et al. Competitividade relativa de soja com arroz-vermelho. Planta Daninha, v. 27, n. 1, p. 35-40, 2009.

PEDERSEN, B. P. et al. Ecological fitness of a glyphosateresistant Lolium rigidum: growth and seed production, along a competition gradient. Basic Appl. Ecol., v. 8, n. 1, p. 258-268, 2007.

RADOSEVICH, S. R. Methods to study interactions among crops and weeds. Weed Technol., v. 1, n. 3, p. 190-198, 1987.

RADOSEVICH, S. R.; HOLT, J. S.; GHERSA, C. $\mathrm{M}$. Ecology of weeds and invasive plants: relationship to agriculture and natural resource management. 3.ed. Hoboken: Wiley, 2007. 454 p.

RIGOLI, R. P. et al. Habilidade competitiva relativa do trigo (Triticum aestivum) em convivência com azevém (Lolium multiflorum) ou nabo (Raphanus raphanistrum).

Planta Daninha, v. 26, n. 1, p. 93-100, 2008.

RIZZARDI, M. A. et al. Interferência de populações de Euphorbia heterophylla e Ipomoea ramosissima isoladas ou em mistura sobre a cultura da soja. Planta Daninha, v. 22, n. 1, p. 29-34, 2004.

ROUSH, M. L. et al. A comparison of methods for measuring effects of density and proportion in plant competition experiments. Weed Sci., v. 37, n. 2, p. 268-275, 1989.

SHRESTHA, A. et al. Growth, phenology, and intraspecific competition between glyphosate-resistant and glyphosatesusceptible horseweeds (Conyza canadensis) in the San Joaquin Valley of California. Weed Sci., v. 58, n. 1, p. 147-153, 2010.

SILVA, D.R.O. Competitividade e características genéticas de Conyza bonariensis resistentess e suscetíveis ao glifosato ocorrentes no Estado do Rio Grande do Sul. 2012. 137 f. Tese (Doutorado em Fitossanidade) Universidade Federal de Pelotas, Pelotas-RS, 2012.

VARGAS, L.; SILVA, A. A. Resistência de Euphorbia heterophylla a herbicidas inibidores da ALS. In: AGOSTINETTO, D.; VARGAS, L. (Ed.). Resistência de plantas daninhas a herbicidas no Brasil. Passo Fundo: Berthier, 2009. p. 143-174.

VILA-AIUB, M. M.; NEVE, P.; POWLES, S. B. Evidence for an ecological cost of enhanced herbicide metabolism in Lolium rigidum. J. Ecol., v. 97, n. 4, p. 772-780, 2009.

WARWICK, S. I. Genetic variation in weeds E with particular reference to Canadian agricultural weeds. In: KAWANO, S. (Ed.). Biological approaches and evolutionary trends in plants. New York: Academic Press, 1990. p. 3-17. 